\title{
ЗАКगЮЧЕНИЕ
}

Экспериментально проверено положение Вавилова об интерференции естественных пучков света, пропедпих через оптически активную среду. Интерферендия изучалась в зависимости от толшины активного слоя, т. е. от углов, в которых заключается поворот плоскости поляризации поляризованных пучков. С увеличением әтого угла контрастность интерференционных полос уменьпается и при угле $90^{\circ}$ полосы полностью исчезают.

В заключение пользуюсь случаем поблагодарить доктора Б. Юрка, который предложил мне провести этот эксперимент и в течение работы давал ценные советы, а также остальных сотрудкнпов оптической лаборатории ЧСАН, которые помогали мне в этой работе.

Поступило 11. 11. 1957.

\section{THE INTERFERENCE OF TWO BEAMS OF LIGHT PASSING THROUGH OPPOSITELY ROTATING MEDIA}

\author{
(Abstract of preceding paper) \\ Milena Závětová \\ Institute of Technical Physics, Czechosl. Acad. Sci., Prague
}

The purpose of the experiment was to verify Vavilov's assertion on the interference of two beams of natural light, after passing through oppositely rotating optically active media $[1,2]$.

Monochromatized light, which after passing through a circular diaphragm fell perpendicularly on two eircular openings, was used for the interference. The interference pattern was photographed in the focal plane of the telescope. A varying number of optically flat quartz plates cut perpendicular to the optical axis were placed in front of the openings, the thickness of the individual plates being chosen so that each rotated the plane of polarisation by $(180-15)^{\circ}$.

The relation in the text gives the calculated course of the intensity in the diffraction pattern of the two circular openings, where $l$ is half the distance between the centres of the openings, $a$ is the radius of the openings, $\lambda$ is the wavelength, $f$ the focal length of the telescope, $J_{1}(y)$ the Bessel function of the first order and $x$ denotes the distance from the centre of the interference pattern. The numerical solution for our case gives the curve in Fig. 1. Fig. 2 shows the measured course of the intensity plotted for three cases: $0^{\circ}$ corresponds to the case without an optically active medium; $30^{\circ}$ denotes the case when one of the rays has passed through one dextro-rotatory and the second through one laevorotatory plate, and finally $60^{\circ}$ corresponds to the passage of one ray through two dextrorotatory and the second through two laevo-rotatory plates. These cases are denoted in Fig. 3 by the consecutive indices $\mathrm{a}, \mathrm{b}$ and $\mathrm{c}$; the photograph marked $3 \mathrm{~d}$ corresponds to the passage through three dextro-rotatory or laevo-rotatory plates respectively.

On the central area of the diffraction pattern, which was produced by diffraction on one circular opening, a system of parallel light and dark fringes was distributed, the contrast in which decreased on increasing the number of plates rotating in opposite directions. When the mutual rotation was equal to $90^{\circ}$ the parallel lines disappeared. The result of the experiment can be interpreted on the basis of the classical theory of interference.

Received 11. 11. 1957.

$$
\text { Iumeparnypa - Rejerences }
$$

[1] Вавплов С. И.: Ивв. АН ССGP (1932), 1451.

[2] Вавилов С. И.: ,Микроструктура света". Ивд. АН СССР, Москва, 1950. 